\title{
Black Sailors on Red Clydeside: rioting, reactionary trade unionism and conflicting notions of 'Britishness' following the First World War
}

Jacqueline Jenkinson

University of Stirling

\section{I}

During the Glasgow harbour riot of January 1919 black British colonial sailors were branded as unfair economic competitors by the national seamen's unions and their local delegates, chased out of the merchant marine hiring yard by white sailors when they sought jobs, beaten in the street, attacked in their boarding house and then targeted for mass arrest by police called in to halt the disorder.

The riot was one of many during 1919 as the working class in general and ex-service personnel in particular took to the streets in violent demonstrations of dissatisfaction with the post-war employment, housing and pensions situation. ${ }^{1}$ The frustrations within society evident in the widespread rioting of 1919 were in the seaports focused on racialised minority ethnic populations who were regarded as an 'alien' element in the British workforce. The riot in Glasgow was soon followed by others in South Shields, Salford, London, Hull, Liverpool, Newport, Cardiff and Barry. Five people were killed in the wave of port rioting, dozens more were seriously injured and there were over 250 arrests as the police, and often troops, struggled to control the rioters. In these nine seaport riots, hostile crowds of white working class people abused and attacked black, 
Arab, Chinese and south Asian workers, predominantly British colonial sailors. ${ }^{2}$ During the war thousands of colonial subjects were attracted to the metropole to fill employment gaps and many of the new arrivals settled in the ports. Post-war, their continued presence became a source of white working class resentment.

The port rioting was triggered by intense job competition among merchant seaman. Rapid post war demobilisation ${ }^{3}$ led to high unemployment in the merchant navy as the industry experienced early the post-war economic depression that did not fully take effect in most of Britain until 1921.

The operation of a 'colour' bar by sailors' unions heightened dockside tensions around Britain's seaports. Prominent Glasgow labour leaders enforced and supported the 'colour' bar on black and Chinese sailors. They opportunistically played on this manufactured division within the low-paid and low-skill seafaring workforce as part of the wider campaign for a 40-hour week to reduce unemployment pressures caused by mass demobilisation. In the few days between the harbour riot and the notorious 'Bloody Friday' riot involving strikers' in the city's George Square, trade union leaders endeavoured to involve white British sailors in the general strike called in Clydeside, by tying ongoing white sailors' protests against the 'unfair' competition posed by overseas labour to the 40-hours strike action.

Two of the Glasgow labour leaders who sought to marginalise black and Chinese colonial workers were subsequently mythologised under the banner of 'Red Clydeside' and later played prominent roles in national politics. Emanuel Shinwell served Labour in parliament in every decade between the 1920s and 
1980s and was appointed a minister in the Attlee government, while Willie Gallacher became a leading member of the Communist Party of Great Britain and served as an MP for fifteen years. Given this wider context, it is not too much to claim that the events surrounding the Glasgow harbour riot reflect Britain's uneven metropolitan and colonial relationship, and illustrate a general feeling of political instability via government fears over Bolshevism associated with strike action in the period. Peacetime issues facing the organised labour movement are also highlighted through the concerted actions of trade unions taken in the belief that full employment was to be one of the first casualties of peace.

In spite of the serious and widespread extent of the port riots and their broad impact around the British Empire; for example, African Caribbean sailors repatriated to the West Indies launched revenge attacks on white sailors and businesses in the months following the riots; they have remained largely overlooked by 'mainstream' historians of the period. ${ }^{4}$ The riots have, however, been discussed by a number of writers on black and immigration history. ${ }^{5}$

One aspect of the riots commented upon by historians is the conflicting attitudes among white and colonial black British residents towards their relative positions in the British imperial hierarchy. Rowe stated that 'while whites viewed blacks as foreign, different and inferior, blacks viewed themselves as citizens and defenders of the British Empire. ${ }^{6}$ Holmes noted that 'the incidents in the ports were... a reflection within a metropolitan context of the racialism that had developed as a result of British imperial and colonial rule. ${ }^{77}$ While the outbreak of the 1919 seaport riots have therefore been measured against constructed 
'meanings' of national identity, this article incorporates the expressed opinions of black working and middle class British residents on their status and imperial obligations. ${ }^{8}$

The broader issue of what may be crudely described as 'race' and labour has been addressed in several studies. ${ }^{9}$ Works by Lunn and Tabili have considered the often racist campaigns and actions of the leading sailors' organisation, the National Sailors' and Firemen's' Union and the relationship between colonial workers and trade unions' in the merchant shipping industry. ${ }^{10}$ Lunn has indicated that such broad consideration of union activity should reflect, wherever possible, local as well as national views and policy. ${ }^{11}$ Events in Glasgow in 1919 are used here as a means to present a local interpretation of the national sailors' union's hostile stance towards black sailors.

Personal accounts of the 40-hours strike and this period in the history of 'Red Clydeside' have overlooked the riot at Glasgow harbour. Although the events were linked, the memoirs of Gallacher and Shinwell and Harry McShane's account of the 40 -hours strike fail to mention it. ${ }^{12}$ Historical accounts too, have ignored the riot. This may be due to a combination of the fact that the harbour rioting is not featured in the personal recollections of 'Red Clydeside' and as a matter of convenience since the riot and organised trade union opposition to the employment of black sailors does not sit well against the politically-radical image of industrial relations on the Clyde. 


\section{II}

The riot on Thursday 23 January 1919 began in the yard of the mercantile marine office in James Watt Street where sailors gathered for their chance to be signed on to a ship. While waiting to see if they would be hired, competing groups of black and white sailors jostled and shouted insults at each other. This baiting descended into a pitched battle which spilled out of the yard onto the street. ${ }^{13}$ More than thirty black sailors fled the sailors' yard pursued by a large crowd of white sailors. White locals joined the crowd which grew to several hundred strong. The rioters used guns, knives, batons and makeshift weapons including stones and bricks picked from the street. On being chased out of the hiring yard, the group of black sailors initially ran towards the nearby Glasgow sailors' home on the corner of James Watt Street and Broomielaw Street. ${ }^{14}$ The white crowd smashed the windows of the sailors' home and then invaded it. The two or three beat police officers in the harbour area were overwhelmed and an additional force of 50 police officers was called in. The large police force cleared the two sets of rioters out of the sailors' home.

The black sailors fled along the broad street parallel to the River Clyde into their own boarding house at 118 Broomielaw Street. White rioters sought to force the sailors back out into the street by smashing the windows with missiles, surrounding the building and then attacking it. In response, some of the black colonial sailors fired shots down at the crowd. Police later found a revolver with three spent cartridges under a bed and five live cartridges lying in the hallway. 
Cornered in their boarding house the black sailors offered no resistance when the police force entered the premises. However, to restore order, the police removed 30 black sailors from the boarding house and into 'protective custody'. All were subsequently charged with riot and weapons offences. None of the large crowd of white rioters was arrested.

Three people were seriously injured during the riot. Two were white sailors: Duncan Cowan who was shot and Thomas Carlin who had been stabbed. Black West African sailor Tom Johnson was also stabbed. Cowan and Carlin were taken directly to hospital. Johnson, despite suffering from wounds to the back and leg, was arrested, brought before a magistrate and formally charged with shooting offences. Johnson's injuries, later described in his hospital record as 'gaping' wounds, were ignored or dismissed as irrelevant by the police and the white crowd. Johnson was removed from the riot scene in a police van, to the obvious pleasure of the white crowd who showered abuse on him as he was driven away for a court appearance. ${ }^{15}$ Local press reports displayed little sympathy for Johnson, who was described in racist terms as: '... a darkie from Sierra Leone, who speaks little English, complained of having been stabbed, but his wound was not serious. ${ }^{16}$ In contrast to the immediate arrest of the wounded Johnson and the mass detention of a group of black sailors, only one white person was later arrested for an alleged assault on a police officer during the riot. The court cases which followed the rioting will be discussed later.

Protest against the employment of colonial sailors so forcefully demonstrated during the Glasgow harbour riot became part of a wider trade 
union campaign against the threat to employment prospects and workers' rights following the end of the First World War. Leading trade unionists advocated the introduction of shorter hours to spread available work around existing workers and returning soldiers. The Scottish Trades Union Congress proposed the introduction of legislation to enforce a maximum working week of 40 hours to coincide with mass demobilisation. ${ }^{17}$ In support of this campaign strikes were called in key Glasgow industries at the beginning of 1919.

Some of the strike leaders, including former sailor and prominent local engineering shop steward Willie Gallacher, ${ }^{18}$ addressed meetings of merchant sailors in order to gain their support for the strike. Emanuel Shinwell, ${ }^{19}$ vocal leader of the Glasgow branch of the British Seafarers' Union, also played a prominent role in the 40 -hours strike campaign.

Clydeside in 1919 held an almost unique position within British industrial production. Its heavy commitments in engineering and shipbuilding and high profile wartime trade disputes meant that employers, including the government, were wary of dealing with trade unions on 'Red Clydeside' long before the unrest surrounding the 40 -hours strike. ${ }^{20} \mathrm{~A}$ series of wildcat engineering strikes was held on the Clyde during 1915. In 1916 members of the alliance of trades' union shop stewards, the Clyde Workers' Committee (CWC) were twice prosecuted under the wartime Defence of the Realm Act for criticising the war in the CWC journal, the Worker and for allegedly campaigning against the Munitions Act which forbade engineers from leaving the works where they were employed. CWC 
members including Willie Gallacher were jailed or deported from the Glasgow wartime production area for their 'unpatriotic' industrial protests. ${ }^{21}$

The general strike of January 1919 was in keeping with wartime industrial disputes on the Clyde. The strike began in Glasgow on Monday 27 January and within two days 70,000 workers had ceased production in engineering, shipbuilding, railway, electrical work and on the docks. Many thousands more workers around Scotland, in Belfast and on Tyneside also struck in support of a reduced working week.

As the campaign gathered momentum, the Glasgow strike committee telegraphed the government proposing a convention to discuss the trade unions' proposals for a shorter working week. The government was in no mood to conciliate and regarded the mass public meeting planned by the strike committee as a provocative political gathering which threatened public order. The matter was discussed in cabinet on Thursday 30 January. With Prime Minister Lloyd George at the Versailles peace talks, Bonar Law chaired the meeting: 'Mr Bonar Law said that he thought it vital for the war cabinet to be satisfied that there was sufficient force in Glasgow to prevent disorder... It was certain that, if the movement in Glasgow grew, it would spread all over the country. ${ }^{22}$

The protest meeting at the municipal city chambers at George Square on Friday 31 January descended into a riot caused by police actions. ${ }^{23}$ Police on horseback and on foot mounted a baton charge on the crowd, injuring 34 people, some of them bystanders unconnected to the demonstration. Nineteen police officers were also injured in the riot. Some members of the crowd fled, while 
others fought back, bringing the centre of Glasgow to a standstill as running battles spread out from George Square to surrounding streets. The Riot Act was read and the strike leaders arrested. Among them were Emanuel Shinwell who was later convicted of incitement to riot and given a five months' jail term, and Willie Gallacher who was imprisoned for three months.

At a further cabinet meeting held hours after the 'Bloody Friday' riot, the Secretary for Scotland, Liberal MP Robert Munro, whose Scottish office and influence were based at Whitehall, alarmed his colleagues with his assessment of the situation: ' $\ldots$ it was a misnomer to call the situation in Glasgow a strike - it was a Bolshevist rising. ${ }^{, 24}$ The cabinet ordered troops and tanks to be despatched to Glasgow that night. The following morning, 12,000 troops, 100 lorries and six tanks were moved into Glasgow city centre.

The government's refusal to negotiate with the Glasgow strike committee, the comments of cabinet members and the summary despatch of troops to the city in the wake of the George Square riot are indications of how seriously it took the influence of the Russian Revolution upon militant sections of the working class in Britain. The same meeting of the cabinet which decided to despatch troops to Glasgow also heard news of the general strike in Belfast from the Chief Secretary for Ireland who reported that workers in the city had formed 'a "Soviet" committee. ${ }^{25}$

The post-war reactivation of the Triple Alliance of transport, railway and miners' unions also brought with it concerns about 'direct action' and of a political general strike which could push the country towards revolution. In response to 
the mounting apparent threats, the government hastily convened a 'national industrial conference' of employers' organisations, trade unions and joint industrial councils on 27 February to discuss working hours, wages and the setting up of a joint council of employers and trade unions to advise on economic issues. $^{26}$

Industrial relations remained volatile throughout 1919. The year began with soldiers' strikes over delays in demobilisation and in August there was a police strike in Liverpool and parts of London. ${ }^{27}$ The numbers of strikes and lock outs in the metal, engineering and shipbuilding, textiles and transport industries were the greatest of any year between 1913 and the General Strike of $1926 .{ }^{28}$ Although the 40-hours strike in Glasgow was brought to an unsuccessful conclusion in mid February, the government made concessions over pay and hours during later disputes. Railway workers achieved an eight hour day and additional pay for night duty, overtime and Sunday working. The miners' were given a 20 per cent pay increase and were granted a seven hour working day. ${ }^{29}$ During 1919, 2.4 million workers were involved in strike action; by comparison, 2.7 million went on strike in defeated Germany and 1.3 million in France in the same year. ${ }^{30}$

Fears of 'direct action' leading to revolution induced the cabinet's industrial unrest committee to lay plans for a 'citizen guard' to deal with the potential dangers of a sustained general strike, in particular to run and protect public utilities. ${ }^{31}$ The citizen guard was never formed and the military continued to have a role in industrial contingency arrangements. Troops were called in to quell port 
rioting in South Shields and south Wales, during the police strike in Liverpool and to protect railway stations in Glasgow and London during the autumn rail strikes.

III

The staging of a general strike in Glasgow, its collapse following 'Bloody Friday' and the presence of tanks in the centre of the city were far more eye catching than the riot at the harbour a week earlier; however, the two episodes ought to be viewed together. The harbour riot and the George Square demonstration occurred within a few days of each other. This proximity was more than coincidental. The two events were explicitly inter-connected through the activities of members of the leadership of the 40-hours strike movement. Shinwell, leader of the Glasgow branch of the Seafarers' Union, was, in addition, president of the Glasgow trades and labour council and chairman of the workers' strike committee. Although a political moderate, he advocated direct action in the most inflammatory terms in the days leading up to both the harbour riot and the mass strike protest of the 40-hours campaign. He and other strike leaders such as Gallacher sought to encourage unskilled workers including seamen to take part in the sort of strike action that had been the province of the skilled workforce on wartime Clydeside. Shinwell's later conviction for 'incitement to riot' was both for his presence as a strike leader at the George Square demonstration on 31 January and also for his speeches on prior days at James Watt Lane, outside the mercantile marine yard where the harbour riot broke out. 
During these waterfront speeches, Shinwell dragged the well-worn debate among white British merchant sailors about the 'unfair' competition provided by overseas labour into a wider industrial setting. He offered dissatisfied white British merchant seaman an opportunity to voice their concerns about workers from overseas undercutting their wages and threatening their job opportunities as part of the wider strike action, in return, the rioting at the harbour and the threat of more in the succeeding days drew additional public attention to the 40 -hours campaign.

Shinwell addressed a meeting of over 600 sailors at the mercantile marine yard a few hours before the harbour riot broke out on 23 January. He drew attention to the large number of 'British' sailors who were already unemployed and the large number yet to be demobilised who would find it difficult to secure employment aboard ship: 'This he attributed to the refusal of the Government to exclude Chinese labour from British ships, and it was essential, he said that action should be taken at once'(author's emphasis). ${ }^{32}$ There is no direct evidence that Shinwell's words incited the riot, however, the rioting served two purposes: the disorder at the port made local shipping employers more reluctant to hire Chinese and black British sailors. More broadly, the riot highlighted the volatile state of workers in Glasgow at this period, a factor which for Shinwell may have suggested itself as a good bargaining tool in negotiations with the government during the 40-hours campaign.

In an interview published in a local evening newspaper the day after the harbour riot, Shinwell hinted that further violence was likely: 'Last night when I 
arrived at the Broomielaw, large crowds were hanging about, and I had considerable difficulty in restraining them from taking further action. ${ }^{33} \mathrm{He}$ explicitly connected the harbour riot to the hiring of overseas sailors in Glasgow, by stating that 'some of the best ships' were employing black and Chinese labour, while a number of recently-demobilised (white British) Royal Naval Reservists were unable to obtain employment. ${ }^{34}$

Over the next few days Shinwell continued to speak out at sailors' meetings against the threat to jobs due to the employment of 'Asiatic' labour on British ships, but he also broadened the nature of the protest meetings. The Scottish press reported that the topic had been brought into the 40-hours strike campaign. The Scotsman noted that if 'such labour' could be cleared from British ships it would provide more job opportunities for (white) British sailors: 'On this subject considerable feeling exists - as was manifested by the riotous incidents in the Broomielaw on Thursday last. ${ }^{35}$ The day before the general strike descended into violence on 'Bloody Friday' Shinwell presided over a third meeting of sailors in a week, where he '... urged them to take effective steps to prevent the employment of Chinese labour on British ships.... ${ }^{36}$

Although sailors and also shore workers from the British Seafarers' Union joined the 40-hours campaign, their presence was overshadowed by the tens of thousands of skilled workers who dominated the strike movement. In addition, despite his firebrand seafront speeches, Shinwell's own role during the course of the 40-hours dispute was largely as a figurehead. Instead, the Clyde Workers' Committee which had presided over the wartime engineering strikes was again 
prominently involved during the 40-hours dispute. In fact, Nan Milton described the strike as the tail end of wartime protest activities by the Clyde workers'

movement. ${ }^{37}$ Yet the support of Shinwell's union members was courted by the strike leadership. Willie Gallacher, who was an acknowledged leader of the 40hours' strike movement and had also been prominent in the wartime Clydeside industrial disputes, joined with Shinwell on 28 January to address 'sea-going' members of the British Seafarers Union and other unionised sailors at the harbour to persuade them to take part in the strike action. The tenor of this meeting was no different from the ones addressed only by Shinwell; again, the tactic was to import the 'old demand' that black and Chinese crews should be expelled from British ships into the broad strike campaign. ${ }^{38}$ Hence, while Shinwell's role in the general strike should not be exaggerated it is clear that the strike committee viewed support from white sailors as useful in widening the 40hours protest movement and were none too particular as to how such involvement was secured.

\section{IV}

A week after the Glasgow harbour riot a brief, emotive account appeared in the Seaman, 'the official organ' of the National Sailors' and Firemen's' Union. The article was short on detail; instead, it sought to portray the violence and lawlessness of the riot scene: 'As one onlooker expressed it... the Broomielaw resembled a 'town out West. ${ }^{39}$ 
The organised sailors' campaign against the employment of 'cheaper' colonial and overseas labour evident at the time of the harbour riot was of longstanding. Life in the merchant naval service featured low pay, lengthy periods of overseas service, poor working conditions, disrupted lifestyle, contract work and intervals of unemployment. In an attempt to encourage and maintain membership among this poorly paid and peripatetic workforce, sailors' unions had campaigned since the 1890s to exclude Chinese seamen from British merchant ships. Black British sailors were often grouped together with 'Asiatic' sailors as potential threats to the livelihood of white British workers in the industry.

Following the successful 1911 seamen's strike a national wage rate for sailors hired in Britain was established. White Britons, white Europeans and thousands of black British sailors sailed on fixed contracts, i.e. 'standard articles' (and received equivalent pay rates). However, those hired overseas could still be contracted for lower wages and ship owners increasingly looked to augment this pool of workers. ${ }^{40}$ British shipping companies hired sailors of various nationalities at overseas ports under distinctive, lower-paid contracts. For example, those on 'Lascar articles' - i.e. south Asian sailors - and other colonial sailors employed directly by shipping companies under specific guidelines (such as the Liverpoolbased Elder Dempster line which directly recruited sailors from West Africa), received wage rates $20 \%-50 \%$ less than the standard rate. ${ }^{41}$ The Royal Mail Line directly recruited African Caribbean seamen on similar unequal terms. Chinese sailors hired overseas were also paid less than the national rate. Such unequal 
pay rates contributed to attacks on Chinese-owned properties in Cardiff during the 1911 sailors' strike. ${ }^{42}$

Black colonial sailors hired in British ports (such as those who sought employment at Glasgow in January 1919) were better paid that those hired outside British waters, but they faced an increasingly competitive post-war job market. Black sailors from the British colonies had also to deal with the perception among white local port dwellers that they were part of a lower paid overseas workforce which, it appeared, was depriving (white) British workers of their livelihood. A press account of the Glasgow harbour riot stated: 'The trouble began because the blacks were being given preference over the whites in signing on for a ship about to sail. The whites resented this, especially as it is well known that coloured men are paid lower wages. ${ }^{, 43}$

The two main seamen's unions active on Clydeside were the largest sailors' union, the National Sailors and Firemen's Union (NSFU) founded in 1894 and run by sometime Liberal MP Joseph Havelock Wilson, and its more politically-radical rival the British Seafarers' Union (BSU) formed as a breakaway organisation in 1911. Although many black sailors joined the NSFU, the union displayed at best, an ambivalent stance to their presence on British ships. While the NSFU encouraged sailors from overseas to join, it also engaged in consistent pressure group activity in an attempt to reduce the potential pool of alien workers, for example by campaigning to strengthen maritime regulations governing language requirements for merchant service. At a local level, the Glasgow branch of the NSFU used the union's enhanced wartime influence over the hiring of 
crews to introduce a post-war ban on the employment of black sailors from the port. The Glasgow NSFU branch cited severe job shortages for its action. One estimate at the time of the harbour riot suggested that between 400 and 500 white sailors remained unemployed in Glasgow. ${ }^{44}$ The local NSFU decision attracted hostile comment from the black British press, with the African Telegraph calling it 'a disgrace to Glasgow. ${ }^{45}$ The ban on the employment of black sailors introduced by the local branch of the NSFU was taken a stage further by the Glasgow branch of the British Seafarers' Union which excluded black sailors from membership altogether.

Concerted union action against black sailors at both national and local level rendered them 'outsiders' among the seafaring workforce. The black sailors who were abused, chased and attacked during the Glasgow harbour riot were regarded as interlopers who had come to snatch jobs from white British sailors. In a newspaper interview the day following the harbour riot Shinwell blamed the violence on a combination of the arrival in Glasgow of black West African sailors from Cardiff with the recent appearance of a group of Chinese sailors from Liverpool. ${ }^{46}$ Several days later Shinwell's opinion was recorded as fact in the same newspaper: ‘evidently some Chinese sailors had also arrived in Glasgow at the same time, and the black men got the benefit of any ill-feeling directed against the Chinese. ${ }^{47}$

Comments by David Cook, the black sailors' defence lawyer, support the view that some of the black Britons attacked during the riot had recently arrived from Cardiff. 'Some of them had formerly sailed from Glasgow, but on this 
occasion a number of men had come from Cardiff to man ships in Glasgow Harbour. ${ }^{48}$ Another local newspaper seized on Cook's statement and chose to distort it to suit prevailing beliefs regarding sailors from overseas, stating that the riot had broken out because white sailors believed black sailors had come up from Cardiff 'to take their jobs. ${ }^{49}$

\section{V}

In his survey of labour relations and issues of 'race' Lunn argued that historically expressions of racist hostility were closely tied to questions of employment. ${ }^{50}$ The imposition of a 'colour' bar on black workers at Glasgow and elsewhere around Britain's seaports to protect white British sailors' jobs illustrates the disregard for sections of the working class among many of those who considered themselves protectors of the organised workforce. Hostility towards groups of fellow workers among trade unionists was nothing new. The opposition of white union leaders and many of their members to the employment of (in some cases) cheaper overseas merchant sailors violently demonstrated at Glasgow harbour bears comparison to the wartime industrial action on Clydeside which aimed at preventing the 'dilution' of skilled with unskilled labour amid fears for skilled job losses and the permanent undercutting of engineers' wages.

At the time of the port riots a variety of contemporary commentators drew attention to these intra-class divisions. Lawyer David Cook noted during the harbour riot trial, 'it was strange that so democratic a body as the Seafarers' 
Union should object to the accused being members. ${ }^{.51}$ Cook's irony was directed at the avowedly more radical of the two main sailors' union playing the 'race' card to attract and mobilise white members at the expense of their black co-workers.

During the wave of summer port rioting, similar critical comments were directed against the sailors' unions - albeit for political rather than legal purposes - in the socialist press. Two revolutionary Marxist newspapers attacked the liberal-dominated seamen's unions and the organised labour movement as a whole, for marginalising black fellow workers out of narrow self-interest.

The Workers' Dreadnought, the weekly newspaper of Sylvia Pankhurst's Workers' Socialist Federation (WSF), printed an article in early June 1919 entitled, 'Stabbing Negroes in the London Dock Area' which drew a vivid picture of intra-class strife during rioting in the capital. The London port violence and the competition for work which provoked it were described as by-products of capitalism. 'Do not you know that if it pays to employ black men employers will get them and keep them even if the white workers kill a few of the blacks from time to time?' ${ }^{52}$ Two weeks later the Workers' Dreadnought returned to the subject of riots; on this occasion NSFU actions were condemned.

The Seamen's and Firemen's Union has placed its ban upon the employment of Negro seamen, so they are ashore and cannot get away. They are attacked and if they retaliate they are arrested! Is this fair play? The fight for work is a product of capitalism: under socialism race rivalry disappears. ${ }^{53}$ 
In July 1919 an article entitled 'Race Riots and Revolution' in the monthly newspaper of the Socialist Labour Party (SLP), the Socialist , implied that the trade union movement was complicit in the capitalist system's exploitation of the 'colour' issue to keep workers divided:

The Trades Unions have prided themselves on having ousted coloured labourers from certain occupations... The very existence of capitalism depends upon driving all the elements of present day pugnacity, a trait always in prominence after a great war, into racial or national avenues. By forcing the workers to ease off their pugnacity over lines of colour, this blinds them to the class line which forms the focus of the struggle of the modern international proletariat. ${ }^{54}$

The Socialist article also compared the manufactured divisions between black and white to those created by organised labour between unskilled and skilled workers: 'Black men and yellow men have been attacked for doing precisely what white men do. This, of course, is but the logical development of the Trades Unions' policy which is prepared to strike rather than that any unskilled white worker should get a "skilled job."”55

The Socialist and Workers' Dreadnought articles offered politically radical explanations for the port riots and at the same time condemned the sailors' unions for dividing workers and playing into the hands of employers. On the far left of the labour movement, the WSF and SLP differed from many in the labour mainstream in that they expressed outrage at racist treatment by trade unions 
towards sailors from overseas. Davis's work on Pankhurst has identified an understanding of imperialism and its association with the ideology of racism as one of the distinguishing features of the Workers' Dreadnought. ${ }^{56}$ Meanwhile, the Socialist Labour Party, influenced by French syndicalism and militant American 'laborism', eschewed party politics and had little time for conventional trade unionism. Hence, the complicit role of seamen's unions in the outbreak of the port riots was highlighted in the pages of both journals.

The traditional hostility of organised labour to the employment of workers from overseas was most notably demonstrated in the series of TUC annual congress resolutions passed in the late 1880s and 1890s against the employment of immigrant labour in Britain. The position taken by the WSF and the SLP also differed markedly from the racist views given a platform in the moderate labour daily newspaper, the Daily Herald in April 1920. E. D. Morel, Independent Labour Party member and future Labour MP, wrote an article expressing 'horror' at alleged predatory sexual behaviour by black colonial French troops against white European womanhood. The troops Morel described as 'black savages' were part of the French army of occupation in defeated Germany. ${ }^{57}$

\section{VI}

The court cases which followed the Glasgow harbour riot underlined the exposed and uncertain status of black colonial Britons in the metropole. The black workers 
attacked in Glasgow were regarded by the white crowd not as fellow Britons caught up in the same contracting post-war job market but as outsiders trying to snatch employment from white British workers. The views of the white crowd which took part in the harbour riot were echoed by sections of the local press. One newspaper account described the black sailors attacked in Glasgow as 'beleaguered aliens'. ${ }^{58}$ The use of the word 'aliens' portrayed the black sailors as 'foreigners' to the Glasgow readership. In fact, the black sailors involved in the riot were British colonial subjects from West Africa. Yet the same press account referred to their attackers as 'a hostile crowd of British and other whites'. The presence of foreign-born 'other whites' at a time of increasing competition in the seafaring job market was not commented upon. ${ }^{59}$

Misapplication of the term 'alien' is unsurprising in the view of the xenophobia and anti-alienism which was present among sections of the white population during wartime ${ }^{60}$ The neutral descriptive word 'alien' had long since been hijacked by the organised anti-immigration lobby to become a pejorative term. Protests against 'alien hordes' were apparent within the organised labour movement; in sections of the press; and in parliament among campaigning back bench MPs throughout the 1890s and into the early twentieth century. ${ }^{61}$ In spite of the introduction of an element of immigration restriction via the Aliens Act of $1905,{ }^{62}$ parliamentary protests against foreign labour continued up to, during and beyond the war. ${ }^{63}$ There was much in common between the long running campaign among the seamen's unions against 'Asiatic' sailors and wider labour and political protests against 'alien' immigration and employment. In this context 
'alien' served as a shorthand term to label the black sailors in a way which would have been readily understandable to the Glasgow readership.

On 24 January, the day after the riot, 30 black British sailors from Sierra Leone were brought before the central police court charged with having formed part of a riotous 'mob' and of recklessly discharging firearms 'to the danger of the lieges. ${ }^{64}$ Once charged, they were detained in custody. Originally dismissed as 'aliens', several press accounts now commented on the 'Britishness' of the black sailors' surnames.$^{65}$ This was not matched by an appreciation of the men's British identity: 'Most of the accused, although obviously of Negro blood, bore familiar English-sounding surnames, such as Johnson, Davis, Parkinson, Alfred, Pratt, with Tom Friday at the end of the list. ${ }^{66}$

The black sailors arrested in Glasgow had served in the British merchant navy before and during the war. Defence lawyer Cook underlined the sailors' sterling service record at their trial: 'During the whole period of the war and for some years before the war they were manning British ships and were, of course, entitled to the protection of the British Government. ${ }^{67}$

After five days in custody the group of black sailors was brought to trial on 29 January before stipendiary magistrate, Dr. Neilson. Indications of police bias in their handling of the riot were played up in court by Cook. He argued that it was 'peculiar' that although a black man had been wounded no white person had been arrested either for that offence or for playing any part in the rioting ${ }^{68}$

Cook, a well-established lawyer with twenty years experience ${ }^{69}$ exposed the fragility of the police evidence against the black sailors. The prosecution 
lawyer (fiscal), George Smith accepted Cook's not guilty plea against 27 of the defendants. Cook entered a plea of guilty on behalf of the remaining three black sailors - Julius Parkinson, Daniel Pratt and Thomas Cole. ${ }^{70}$ Although all three were found guilty, the weapons and rioting charges originally laid against them were dropped in favour of the lesser charge of breach of the peace. As he gave down the sentences, the magistrate had strong words of condemnation for those convicted: 'the offence was committed under conditions of great gravity, and the result might have been more disastrous. ${ }^{71} \mathrm{Dr}$ Neilson imposed a fine of $£ 3.15$ on each, with the alternative of 21 days' imprisonment.

The lesser convictions given the black sailors following the riot may have been for technical reasons to avoid financial liability. Had the convictions of the sailors been for riot offences this would have rendered Glasgow corporation (council) liable to damages claims such as the one levied by a company whose property was adjacent to the black sailors' boarding house in the Broomielaw attacked by white rioters and from which shots were fired during the rioting. This claim for damages was recorded in the minutes of Glasgow corporation magistrates' committee. After hearing a report on the harbour disorder from chief constable, James Verdier Stevenson, the committee agreed to recommend that liability be repudiated, and authorised the town clerk be to defend any court action raised. ${ }^{72}$ The outcome of the damages' claim was not recorded. It is unlikely to have succeeded since only in cases where a riot was proved to have taken place would the local authority accept liability for damaged property. 
Following the mass trial of black colonial sailors, other individual cases followed, including that of David Samuel, another sailor from Sierra Leone. Samuel was arrested during the police search for the person who stabbed white sailor, Michael Carlin. Samuel had no knife, but was armed with a revolver and twelve cartridges. He was brought before the divisional court on the day of the riot and was remanded on a charge of contravening the Defence of the Realm Act by having a firearm in his possession. ${ }^{73}$

Potentially the most serious case arising from the harbour rioting was that of Tom Johnson, who was initially charged with shooting Duncan Cowan: 'The injured black gives the name of Tom Johnson, and is a stocky little fellow. Against him is preferred the charge that he shot a seaman [Cowan]... ${ }^{, 74}$ Johnson was charged at the Glasgow marine court and then taken to the Western Infirmary for treatment to back and leg wounds. ${ }^{75}$

Surprisingly, Johnson, his alleged victim Cowan, and Carlin, were all admitted to the same surgical ward. Carlin, a 23-year old sailor, was admitted bleeding profusely with cuts to his head. Three wounds to his scalp were treated, including one triangular four-inch skin flap which was stitched in theatre. Carlin was discharged on 3 February after 11 days in hospital. Cowan, an able seaman aged 57 , had been shot in the neck. An infirmary surgeon, Mr Taylor, removed a bullet from Cowan in theatre the next morning and handed it over to a waiting police detective. Cowan was released with his wound healed, the same day as Carlin. 
Tom Johnson spent twenty two days in hospital receiving treatment for stab wounds. Johnson, a seaman, aged 23, gave his address as 118 Broomielaw (the black sailors' boarding house attacked during the riot). Johnson's back wound was described in the hospital ward book as a 'gaping incised wound' which left a 'considerable cavity.' His leg wound above the shin was at first believed to have been caused by a gun shot, but an x-ray showed there to be no bullet in the hole. The wound in Johnson's leg healed slowly and he was not dismissed until 14 February. ${ }^{76}$

There is no indication that Johnson faced charges for shooting Cowan on his release from hospital. It is possible that, like the majority of black sailors arrested, his case was dropped due to insufficient evidence. Newspaper accounts of Johnson's detention suggest it came amid some confusion: 'The Sierra Leone man [Johnson] is alleged to be the person who fired the shot which wounded the British sailor, but in the meantime it is difficult to say anything positive, owing to the excitement which prevailed. ${ }^{77}$

The treatment of black people by the police during the 1919 riots was overwhelmingly biased. Far more black people were arrested than whites in Glasgow and there was a similar pattern at other riot centres in Britain. A superficial examination of the harbour riot trials suggests that the courts did not necessarily follow the police lead. 27 of 30 black people arrested en masse during the riot had all charges against them dropped; meanwhile, the solitary white person arrested as a result of the riot was found guilty and given a comparable sentence to the three convicted black sailors. 
Patrick Cox, a nineteen-year-old sailor, was charged at the western police court with assaulting a police constable in James Watt Street during the riot. In this incident, a group of white people had attacked a 'Chinaman' and knocked him down. Police Constable Russell intervened, but as he assisted the man he was struck from behind. He was unable to identify his assailant, but witnesses identified Cox as the person who assaulted him. Cox was found guilty and fined $£ 3.15$, with the option of 20 days' imprisonment. ${ }^{78}$

Although Cox's sentence was similar to those given to Parkinson, Pratt, and Cole, his offence was not. Cox was found guilty of police assault, a more serious offence than the breach of the peace convictions handed down to the three Sierra Leonians. The similar sentences given down at the riot trials on further analysis do not suggest parity for black and white before the law.

Patrick Cox's arrest and trial provides the only direct evidence of violence against a Chinese person following the protest meeting against 'Asiatic' labour addressed by Shinwell on the day of the riot. In this case, an unidentified Chinese man, an insignificant 'other' was beaten up by a gang of whites in a related, but separate, action of 'scapegoating' following on from the riot at the harbour.

In the 1919 riots around Britain the majority of black people arrested were found not guilty in court. This suggests that there was a difference in approach between the police and the courts. Black prisoners were often freed through lack of evidence and claims by black detainees that they acted in self defence were often accepted by local magistrates. ${ }^{79}$ More broadly, court proceedings may have been influenced by fears of an imperial backlash against perceptions of unjust 
treatment of colonial British subjects. The potential consequences of the port riots for Britain's imperial relationships were expressed in newspaper reports during the outbreak of widespread rioting in June. These were forcefully stated in an editorial in the Liverpool Daily Post and Mercury on 11 June 1919:

Careful and commonsense handling of the 'colour' disturbances is necessary if what at present is little more than a local disorder is not to develop into a serious Imperial problem. There would be infinite possibilities of mischief if any idea gained ground in India and Africa that the isolated conduct of riotous mobs represented the prevailing British attitude towards the black members of the Empire who are in our midst. ${ }^{80}$

Coming from a radically different perspective, a Workers' Dreadnought article printed on 7 June, before the peak of the rioting, presciently raised the possibility that the port riots might provoke a hostile colonial reaction against continued British rule:

We submit a few questions to those who have been Negro hunting: - 'Do you wish to exclude all blacks from England?’ If so, 'do you not think that blacks might justly ask that the British should at the same time keep out of their countries? ${ }^{81}$

Some of the fears of a colonial backlash came to fruition in a spate of riots and strikes which affected the British West Indies in particular, later in 1919. These disturbances often involved repatriated African Caribbean sailors who felt a 
strong sense of grievance against British authority following their ill-treatment in the riot ports. ${ }^{82}$

\section{VII}

Further disorder at Glasgow harbour coincided with the widespread port rioting in summer 1919. On 13 June a confrontation took place on the Broomielaw involving a white crowd and a group of black sailors, some of whom were armed. Police spotted one of the black sailors dropping a revolver in the street. ${ }^{83}$ Two black 'agitators' were arrested and charged with weapons offences. News of this incident reached an already wary government and a week later, a note was sent from the Ministry of Shipping to the Colonial Office predicting further 'trouble' in Glasgow. 'These men are causing much uneasiness and seamen at the port are very disturbed in consequence. ${ }^{, 84}$ The two black people arrested in Glasgow in June initially appeared before the marine police court before remittance to the higher sheriff court. One of the detained men was charged with a serious assault on a white man at the Broomielaw and with 'presenting a loaded revolver' at him. It has not been possible to discover his fate. The other 'coloured seaman', John Robert Bell, was convicted of 'carrying a loaded revolver within the special area of the harbour without permission of the competent naval authority. ${ }^{, 85} \mathrm{He}$ was fined $£ 5$ (or 10 days' imprisonment) for possessing a revolver and six cartridges at Glasgow harbour. 
The Glasgow press recorded these isolated incidents in a small way, but devoted many pages to the outbreak of port rioting elsewhere in Britain at this time. On 18 June 1919, prompted by the wave of unrest, the 'Hal o' the Wynd' 'opinion' column in the Glasgow Evening Times made extremely racist remarks: 'In this country Sambo has been usually regarded with general tolerance. We have looked upon him as an 'amoosin' cuss', who would never create anything approaching a problem... ${ }^{86}$ In utilising such racist terminology the Unionist Evening Times was in step with the dominant trend in the press reporting of the port riots around Britain. The description of black colonial Britons using racist language employed in North America no doubt owed something to the close British public awareness of American practices of discrimination and segregation. Such 'knowledge' was based on information derived from the popular press, novels, theatre and the cinema. ${ }^{87}$ The populist view was also shaped by attendance at 'minstrel shows' which originated in America ${ }^{88} \mathrm{~A}$ further example of racist reporting of the port riots appeared in the Glasgow Evening News (in an article reproduced from the Manchester Guardian). 'The quiet, apparently inoffensive, nigger becomes a demon when armed with a revolver or razor, caring for nothing except the safety of his own skin and the speediest method of overcoming his opponent. ${ }^{89}$ Despite the overt racism of such comments, there is no concrete evidence of press reports actively inciting violence in the ports, although this occurred in the American 'race' riots of 1919. ${ }^{90}$ More likely, press accounts, which constantly portrayed black people in a negative light, exerted an ongoing influence over the susceptible element of their readership. The 'Hal o' 
the Wynd' article went on to cite the recommendation from one its readers that the only way to keep the peace between white and black was through repatriation of the latter.

One of our readers who has been ten years in West Africa directs our attention to the coloured question in Glasgow. The other day he noticed a white girl in the company of three negroes [sic] and he suggests that in the interests of law and order our city authorities should urge the Colonial Office to repatriate our embarrassing visitors immediately. ${ }^{91}$

Such biased press reporting and accompanying reader input did not go unchallenged. Evidently, the readership of the Glasgow press was not homogeneous and the editorial 'voice' of any newspaper did not speak for all of its readers. The 'Hal o' the Wynd' article in the Evening Times provoked several letters of protest. For example, a female correspondent who signed herself 'live and let live', responded that she was not the only white Glasgow female who had married a black sailor and had found the experience suited her.

I think as the white wife of a British coloured man I have a right to speak. 'Hal o' the Wynd' thinks it repulsive to see a white woman in the company of a coloured man. It is a shame to say that. They are as God made them; they cannot help the colour of their skin. We, the white wives know better than anyone what they are. We have been married 
for years and find the British coloured man - I don't say all, but I say most - make us very good husbands. ${ }^{92}$

Another letter from a white Glasgow woman who had been married to a black merchant sailor for twenty five years was published in the Evening Times a few weeks later. Signing herself 'justice for the coloured people' she described how her husband had brought many black friends to stay over the years. These guests she described as 'honourable and respectful' men. Black colonial sailors had made great wartime sacrifices. Her husband had been on ships that were torpedoed on four separate occasions and three black sailors who had visited the house had been drowned and two others been burned to death 'at the hands of the Germans. ${ }^{93}$

'Hal o' the Wynd's' racist opinions were also challenged personally, when three African Caribbean ex-soldiers visited the Evening Times offices to put their case. One man stated that he had served the British Empire for more than four years in the Army Service Corps in both France and Salonika. Another questioned 'why aliens who had done nothing for the country remain here and peaceable British subjects be forced to go ${ }^{\prime 94}$ This comment reveals that some black Britons - although they wanted to be exempt from it - shared the popular xenophobia towards 'aliens' so forcefully demonstrated during anti-alien protests and rioting during the First World War.

Sailors and former soldiers were not the only black residents in Glasgow. By the early twentieth century the city's black population was of long-settlement 
and included families, students, professionals and skilled workers. Glasgow also had a black social club, the Order of the Star of Bethlehem's Shepherds ${ }^{95}$ and its own black political organisation, the African Races Association of Glasgow (ARAG). Following the summer port riots, a letter protesting against the violence from ARAG was published in several of the Scottish newspapers. The Daily Record and Mail, a newspaper with Liberal sympathies, published the fullest account. The letter, signed by ARAG secretary, African Canadian Leo W. Daniels, provides an insight into the middle class black Glaswegian reaction to the port riots.

The members of the African Races Association of Glasgow, view with regret the recent racial riots in different parts of Britain, and resent the unwarrantable attacks that have been made upon men of colour, without exception as one common herd of inferior beings. It seems from the newspaper reports that the seat of the trouble lies in the fact that men of colour are employed at seaport towns, while demobilised soldiers are unemployed. Is it not a fact that there are in the same towns ex-service coloured men also unemployed? But, granting that some coloured soldiers are employed are they not in the minority - about 1,000 to 1 , and are they not British subjects the same as the white men, and consequently deserve the same consideration?

Did not some of these men fight on the same battlefields with white men to defeat the enemy and make secure the British Empire? Why can’t they work now in the same factories with white men? Did they not run the risks of losing their lives by the submarine warfare in bringing food for white women and children in common with white men? ${ }^{96}$ 
Middle and working class black people in Glasgow appeared united in their support for the British Empire: Daniels' comments on the stout colonial defence of the Empire in his letter to the Scottish press echoed the words of African Caribbean ex-soldier Cornelius Johnstone printed a few days earlier: 'every man who is under the British flag has done his share to secure the country. ${ }^{97}$

After a flurry of letters to the press on the subject of the summer port riots, nothing further is known about the activities of ARAG until late 1922 when Daniels appealed to Robert Russa Moton, principal and successor to Booker T. Washington at the renowned African American college, the Tuskegee Institute, Alabama, for financial assistance following a private visit by Moton to Glasgow that year.$^{98}$ After Daniels's unsuccessful appeal for funds, the association dropped from public view until 1928 when news of its affiliation with the West African Students Union (established in London in 1925) was reported in the latter's newspaper Wasu. ${ }^{99}$

The fact that the Glasgow press allowed ARAG a prominent platform during the summer port riots suggests that class distinctions as well as racist attitudes were in evidence in newspaper reactions to the port riots. The association was a middle class organisation, its committee populated by professionals and skilled workers from across the British Empire and beyond, while, according to Moton, the ARAG membership (whom he encountered on his visit to Glasgow) mainly consisted of 'college students.' The 1922 ARAG 
executive featured Dr. Francisco Ribeiro of Accra, the Gold Coast, as chairman; Dr. James Horsham of Meharry Medical College, Nashville, Tennessee, USA was treasurer; and Jamaican James Miller, a ship's joiner, was secretary. ${ }^{100}$ Daniels, a journalist, who by this time was president of the association, was from Ontario, Canada and had lived in Glasgow since 1886.

In keeping with this class-distinction, an internationally-renowned member of the African 'elite' who visited Glasgow and Edinburgh in the year of the harbour riot was also afforded positive press coverage. Sol Plaatje, ${ }^{101}$ the South African National Congress's first president, made two campaigning trips to Scotland. In October 1919 Plaatje gave a lecture to a labour gathering in Glasgow. Reporting the public meeting, Forward, the non-aligned, widely-read Scottish socialist journal noted: 'He is probably the first black lecturer to appear on the Socialist platform in this country. ${ }^{102}$ The Forward article on Plaatje illustrates the sympathetic reaction to 'educated' black people and their world position displayed on occasion by the white 'liberal' British media, which was in contrast to the overwhelmingly negative portrayal of black workers in Britain at the time of the port riots.

\section{VIII}

The rioting at Glasgow harbour served the purposes of organised labour in the industry by further limiting the job opportunities for black sailors. Following the riot shipping employers' were more reluctant than previously to hire black sailors in the port. The increased difficulty in finding employment provoked an organised 
protest campaign as members of Glasgow's black population worked together to publicise the growing destitution among black seafarers caused by long-term unemployment. This campaign suggested a degree of co-operation within Glasgow's black population if not a completely united community. In March 1919, a petition protesting the imposition of the union 'colour' bar on British ships in Glasgow harbour was sent with a covering letter by a group representing 132 black sailors to the ultra-patriotic journal John Bull. ${ }^{103}$ In the letter, the black sailors squarely blamed their current unemployed status on the actions of the seamen's unions who were: '.. working to have coloured men abolished not only from British ships but expelled altogether out of Britain.' The arguments put forward in the Glasgow sailors' letter illustrate the politicising effect of war on black British colonial subjects: 'The great European war have [sic] brought the aspirations of every race to the forefront. We are not living in the stone and iron age, neither are we living in the days when Negroes was [sic] fooled with Bits of Glass and Beads. ${ }^{104}$

The Glasgow sailors' petition was subsequently passed to the Colonial Office, but not before enough information was extracted to provide a sensationalised article for the journal's readership. The John Bull report portrayed the dismal existence of the black sailors in Glasgow and at the same time highlighted the employment of aliens on British ships:

The ... National Sailors' and Firemen's Union... took the disgraceful step of refusing them - although members - to serve on British ships. The only shadow of an 
excuse is the shallow pretence that the places the coloured men would take are to be reserved for discharged soldiers. That is sheer bunkum. One poor fellow has died as the result of privations, and of 'sleeping out' for he had no money and no bed. Yet he was a Briton who had defied the Hun and his devilries for the sake of Britain. There are 132 of these ill-treated fellows in Glasgow most of these without a square meal any and every day. Their appeal to the Lord Provost has been calmly ignored. They are modest enough to say - 'first place for white Britishers; after that coloured Britishers.' Yet they are ordered to 'clear out' from ships at Glasgow, while they see Norwegians, Swedes and Spaniards taken on. ${ }^{105}$

A later report in the African Telegraph in April 1919 took its cue from the John Bull article. 'In Glasgow there are more than 130 British seamen walking on their uppers, down and out. They happen to be coloured men, but they are all true British-born subjects, who have served on British ships during the war.,106

The Glasgow petition was one of several from unemployed black British sailors received by the Colonial Office in spring 1919. Others came in from black Britons at the south Wales' ports of Newport and Barry and also from New York. The Colonial Office response was to refer the petitioners to the Board of Trade repatriation scheme. Repatriation for unemployed black workers had been on offer via the marine department of the Board of Trade since February 1919. ${ }^{107}$ The offer was principally directed at black sailors who had come to Britain during wartime. A more comprehensive government repatriation offer to all black colonial sailors was undertaken after the outbreak of widespread riots in south 
Wales and Liverpool in June 1919 with small cash incentives made available. This extended repatriation scheme was mounted across Britain's major seaports including Glasgow. By August 1921 around 2,000 black people had been repatriated from Britain. ${ }^{108}$

An internal memorandum which commented on the protests from the various black sailors' groups revealed the Colonial Office was powerless to overturn the seamen's union's 'colour' bar. It was unwilling to propose the type of legislation which would be needed to ensure that a proportion of every ship's crew consisted of 'British' subjects: '... I fear we are helpless as regards the Union attitude. ${ }^{109}$

Protests from black British sailors about their lack of employment to the Colonial Office produced a generic letter in response. Unlike the internal civil service discussions, the official reply said nothing about the sailors' unions' intransigence; instead it blamed black unemployment on the 'unusually large numbers of seamen' then in Britain owing to demobilisation from the Navy and the return of sailors from imprisonment in Germany. ${ }^{110}$ The weak Colonial Office response to their requests did not satisfy the Glasgow petitioners. A second letter to the Colonial Office was more strident in tone, noting that they were well aware of the over supply of sailors at that time. The letter returned to the petitioners' chief grievance, namely, that foreign sailors ('Spaniards, Swedes, Greeks and Chinese') were getting jobs while they as Britons were out of work. This second letter also mentioned the riot against black sailors at the Broomielaw as further evidence of the racism then current in Glasgow. It concluded by re-iterating the 
loyalty of the black population using terms which illustrate an awareness of contemporary political debates: 'we are not Bolsheviks... but we wants to enjoy the freedom which is the basis of Great Britain. ${ }^{.111}$ The Colonial Office's reply referred the Glasgow delegates to the department's original letter citing the existing repatriation scheme and stated that they had nothing further to add.

The position of black sailors in Glasgow did not improve over the next few months. In February 1920, a letter from the Glasgow branch of the philanthropic organisation the Charity Organisation Society (COS) to the Scottish Board of Health, which dealt with Scottish welfare matters, stated that there were over 100 black workers in Glasgow who had been unemployed so long they were no longer eligible for out-of-work payments. Most of them had refused repatriation when it was offered since the $£ 5$ inducement with an additional $£ 1$ voyage allowance would not cover the reclamation of goods they had pawned over the months of their unemployment. Some had over $£ 20$ worth of goods in hock. The cos letter reported the death of one man forced to sleep rough, while others were admitted to Glasgow's Barnhill poor house suffering from exposure and hunger. ${ }^{112}$ No voluntary or government agency seemed able to improve the lot of the unemployed black sailors in Glasgow:

The Board of Trade officials in Glasgow have done everything in their power to get them away or get employment but during the past six months not more than half a dozen coloured men got employment from Glasgow, while ships that came in with black crews left many of them behind. The result is that the numbers are gradually increasing. 
Apart from humanitarian considerations, the presence of so many discontented and semistarved men is a positive danger. ${ }^{113}$

The Scottish Board of Health passed the COS letter on to the Colonial Office. The Colonial Office response dismissed the scaremongering tone of the letter and in reply returned to its by now familiar theme: nothing more could be done for black sailors who had refused the offer of repatriation. The National Relief Fund, (which aided ex-service personnel), stepped in to temporarily relieve some of the black Britons left unemployed and destitute in Glasgow. The position of working class black Glaswegians is unlikely to have improved in the immediate future as the post-war recession worsened. For example, in March 1920 the Glasgow Herald reported that 600 former soldiers were destitute and were 'walking the streets' of the city looking for work. ${ }^{114}$

\section{IX}

The riot at Glasgow harbour on 23 January 1919 brought together a number of distinctive features of early twentieth century Britain. The riot was the first instance of a spate of rioting focused upon black residents in British ports which reached their height in June of that year. The harbour riot was also part of the wider picture of industrial strife which had been simmering below the surface on Clydeside and other heavily industrialised regions throughout the war years and into 1919. This broader protest had much to do with organised trades' union 
opposition to wartime dilution policies and support for a shorter working week to preserve employment levels.

The 40-hours campaign on 'Red Clydeside' sought to avert the threat of post-war unemployment. Fears over (white) unemployment also lay behind the campaign by seamen's unions against the use of black and Chinese sailors that spilled over into violence in the rioting at Glasgow harbour. Prominent local trade union leaders were involved in both these workers' campaigns and sought to intertwine them. There was to be no successful outcome of the 40 -hours strike; meanwhile, the movement to limit the employment of black workers in the merchant navy did little or nothing to maintain the wages and job opportunities of white sailors in a declining industry. However, the political credentials of Shinwell and Gallacher, respectively on the moderate and extreme left, were undamaged by the lack of success in these months. For both men their prominent wartime and post-war involvement in workers protests' on Clydeside aided their subsequent rise into the national political arena.

In the wake of the war, the government feared worker insurrection. The cabinet reacted to the Glasgow 40 -hours strike protest by sending a military force to deter further disruption. When widespread rioting broke out in Britain's ports in summer 1919, the government response was once again to despatch troops to riot hotspots including the south Wales ports.

The January 1919 riot at Glasgow harbour reflects the ambiguous and exposed position of many black people in post war British society. As Lunn and others have shown, colonial Britons in the metropole were used as a convenient 
'reserve army of labour' during wartime but soon found their continued presence among the white British working class was resented. This case study of Glasgow has demonstrated that black people were viewed as an 'alien' element in the workforce by white rioters whose violent actions against their employment were ultimately appeased by the launch of an extended programme of repatriation for black colonial residents throughout Britain in summer 1919. Repatriation forced two thousand black workers and their dependents out of Britain under protest; however, thousands more remained and many of these, including black Glasgow residents from various backgrounds, campaigned for a fair chance of employment and to consolidate their position in inter-war British society. 
${ }^{1}$. The National Federation of Discharged and Demobilised Sailors and Soldiers staged a range of coordinated campaigns and demonstrations throughout the country in 1919 and 1920. Their 'monster' demonstration to parliament in May 1919 descended into violence and was broken up by a police baton charge. See House of Commons [HOC] debates, vol. 116, 26 May 1919, col. 991. In Luton in July rioters burned down the town hall, N.G. Orr, 'Keep the Home Fires Burning: Peace Day in Luton 1919’ Family and Community History 2/1 (May 1999), 17. There were also riots in London and Edinburgh. For the London Aldwich riot see the Times, 10 March 1919, 10; 17 March 1919, 8; for the Edinburgh Gayfield square riot see the Glasgow Herald, 10 July 10 1919, 3 and the Bulletin (Glasgow) 7 July 1919, 2.

${ }^{2}$. For the sake of clarity, this article uses the term 'black' to describe people from Africa, those of African Caribbean birth and persons of African descent where no precise information on birthplace is available in the sources.

3 . At war's end the British armed forces consisted of 6.5 million troops and officers. By December 1919 nearly 4 million service personnel had been demobilised. Rapid demobilisation had an impact on unemployment levels. In April 1919 the numbers of unemployed reached 1,093,000.

4. A rare exception is J. Stevenson, British Society 1914-45 (London, 1988), 98, which contains a passing reference to the port riots.

5. See N. Evans, 'The South Wales Race Riots of 1919; Llafur 3, part 1 (1980), 5-29; Evans, 'The South Wales Race Riots of 1919: a documentary postscript; Llafur 3, part 4 (1983), 79-85; Evans, 'Across the Universe; racial violence in the post war crisis in imperial Britain 1919-1925' ch. in D. Frost ed., Ethnic Labour and British Imperial Trade: a history of ethnic seafarers in the United Kingdom, (London, 1995), 59-88; P. Fryer, Staying Power: a history of black people in Britain (London, 1984), 300-316; C. Holmes, John Bull's Island: immigration and British society, 1871-1971 (London, 1988), 95-109; R. May and R. Cohen, 'The Interaction between race and colonialism: a case study of the Liverpool race riots of 1919' Race and Class 16 (1974), 111-126; M. Rowe, 'Sex, Race and Riot in Liverpool, 1919', Immigrants and Minorities 19 (July 2000), 53-70; J. Walvin, Black and White: the Negro and English society 1555-1945 (London, 1973), 202-215; J. White, ‘The summer riots of 1919’ New Society 57 (13 Aug. 1981), 260-1. For in-depth accounts of the 1919 port riots see contributions by J. Jenkinson in R. Lotz, and I. Pegg eds., Under the Imperial Carpet: Essays in Black History 1780-1950 (Crawley, 1987), 182-207 and in P. Panayi ed., Racial Violence in Britain in the $19^{\text {th }}$ and $20^{\text {th }}$ centuries (Leicester, 1996), 92-111.

${ }^{6}$. Rowe, 'Sex, “Race” and Riot', 66.

7. Holmes, John Bull's Island, 109.

${ }^{8}$. An earlier article of mine on the Glasgow riot examined the colonial origins of the black British workers attacked during the rioting. See Jenkinson, ‘The Glasgow Race Disturbances of 1919’ in K. Lunn ed., Race and Labour in Twentieth Century Britain (London, 1985), 53-4. 
9. See for example, Lunn, Race and Labour, in particular his chapter 'Race Relations or Industrial Relations?: Race and Labour in Britain, 1880-1950', 1-29; and L. Tabili, 'We ask for British Justice': Workers and Racial Difference in late Imperial Britain (New York, 1994); D. Frost, ed., Ethnic Labour and British Imperial Trade (London, 1995); and Frost, Work and Community among West African Migrant Workers since the nineteenth century (Liverpool, 1999).

${ }^{10}$. See Lunn, ed., Race and Labour, 10-17; and Tabili, British Justice, 81-112

${ }^{11}$. Lunn, ed., Race and Labour, 17.

12. See W. Gallacher, Revolt on the Clyde (London, 1936); H. McShane, Glasgow 1919: the story of the 40 hours'strike (Glasgow, 1974) and E. Shinwell, Conflict Without Malice (London, 1955). McShane, an engineering union representative, was a Clydeside strike leader and a member of the Independent Labour Party. He later joined the Communist Party of Great Britain.

13. Daily Record and Mail (Glasgow), 24 Jan. 1919, 9.

${ }^{14}$. The central Glasgow harbour area is known locally as the 'Broomielaw', after the long street which runs adjacent to the river Clyde.

15. Daily Record and Mail, 24 Jan. 1919, 9.

${ }^{16}$. Bulletin (Glasgow), 24 Jan. 1919, 2. See also the Glasgow Herald 24 Jan. 1919, 7. In addition to the Bulletin and the Glasgow Herald, two other daily Scottish newspapers were consulted for this article, the Scotsman (Edinburgh) and the Daily Record and Mail. The first three held Unionist (Scottish Conservative) sympathies, the Daily Record was Liberal. Three Glasgow evening newspapers were also consulted: The Evening Citizen; the Evening News and the Evening Times.

${ }^{17}$. I. McLean, The Legend of Red Clydeside, (Edinburgh, 1983, reprint 1999), 112-138.

${ }^{18}$. Willie Gallacher, (1881-1965), worked as a ship's steward on Atlantic crossings before taking up engineering employment in the Albion Motor Works. He was a leading member of the Communist Party of Great Britain founded in 1920. He served as Communist MP for West Fife from 1935-1950.

${ }^{19}$. London-born Emanuel Shinwell (1884-1984) moved with his family moved to Glasgow as a child and began working aged 11. He was leader of the British Seafarers’ Union from 1911 until its collapse 1927. He was elected as Independent Labour Party MP in 1922 for Linlithgow, West Lothian. He lost his seat in 1924, but was re-elected in 1928. In 1935 he was returned to parliament for Seaham, County Durham. He was appointed Minster of Fuel and Power in 1945. He also served as Secretary of State for War from 19471950 and Minster of Defence (1950-1951). He was Chairman of the Parliamentary Labour Party 19641967. He was created Baron Shinwell in 1970.

${ }^{20}$. According to McLean, the term 'Red Clydeside' was an 'established journalistic cliché' by December 1918. See McLean, Legend of Red Clydeside, 154.

${ }^{21}$. For more on wartime disputes on 'Red Clydeside’ see McLean, Legend of Red Clydeside, 5-110; and also McLean, 'Red Clydeside 1915-1919' in R. Quinalt and J. Stevenson eds., Popular Protest and Public Order: six studies in British history, 1790-1920 (London, 1974), 215-242. McLean undermines the radical credentials and political importance of the labour unrest on the Clyde claimed by its participants in their 
memoirs. For contrary arguments that stress the long-term significance of Clydeside industrial protest for the advance of the Labour Party, see J. Melling, 'Whatever Happened to Red Clydeside? Industrial conflict and the politics of skill in the First World War', International Review of Social History, 35 (1990), 3-32; J. Foster, 'Strike Action and Working Class Politics on Clydeside 1914-1919' International Review of Social History, 35 (1990), 33-70, and A. McKinlay and R.J. Morris eds., The ILP on Clydeside 1893-1932: from foundation to disintegration (Manchester, 1991).

22. The National Archives (TNA) Cab 23/9, War Cabinet 522, 30 Jan. 1919.

${ }^{23}$. C. Harvie, No Gods and Precious Few Heroes: Scotland, 1914-1980 (London, 1981), 22.

${ }^{24}$. TNA, Cabinet minutes, Cab 23/9, War Cabinet 523, 31 Jan. 1919.

25. TNA, Cabinet minutes, Cab 23/9, 31 Jan. 1919.

${ }^{26}$. C.J. Wrigley, ed., British Industrial Relations vol. II: 1914-1939, (Brighton, 1987), 163; M.H. Cowden, Russian Bolshevism and British Labor 1917-1921 (New York, 1984), 35

${ }^{27}$. For more on these incidents see A. Rothstein, The Soldiers' Strikes of 1919 (London, 1980) and A.V. Sellwood, Police Strike, 1919 (London, 1978).

${ }^{28}$. Wrigley, ed., British Industrial Relations, 14.

${ }^{29}$. Wrigley, ed., British Industrial Relations, 77-78.

${ }^{30}$. In Paris, a post-war campaign for an eight hour day was mounted under the auspices of the Confédération Général du Travail. The CGT held a mass demonstration and general strike timed to coincide with May Day 1919. The government order forbidding any mass assembly was ignored. Police and troops violently broke up the demonstration and by the end of the day 600 were injured and one worker was killed. See C. Tilly, The Contentious French, (Cambridge, Mass, 1986), 319.

${ }^{31}$. K. Jeffrey and P. Hennessy, States of Emergency: British governments and strike breaking since 1919 (London, 1983), 10-11.

${ }^{32}$. Evening Times, 23 Jan. 1919, 1.

33 . Evening Times, 23 Jan. 1919, 1.

34 . Evening News (Glasgow), 24 Jan. 1919, 5.

35. Scotsman, 29 Jan. 1919, 8. See also Evening Times, 28 Jan. 1919, 1.

${ }^{36}$. Bulletin, 31 Jan. 1919, 10.

${ }^{37}$. N. Milton, John Maclean (London, 1973), 193.

${ }^{38}$. Evening Times, 28 Jan. 1919, 1.

39. Seaman (London), 31 Jan. 1919, 3.

${ }^{40}$. Tabili, British Justice, 42.

${ }^{41}$. I. Law and J. Henfrey, A History of Race and Racism in Liverpool 1660-1950 (Liverpool, 1981), 21.

42. Evans, 'The South Wales Race Riots of 1919', 7.

${ }^{43}$. Evening Citizen (Glasgow), 24 Jan. 1919, 3.

${ }^{44}$. The Bulletin, 24 Jan. 1919, 2. 
45. 'The men now cast on the streets have paid their subscriptions as members of the Sailors' and Firemen's Union , but the officials of the Glasgow branch have made and enforced a rule that no coloured man, even among its own members, be allowed to sail on British vessels.' African Telegraph, vol. 1, Apr. 1919, 184. The African Telegraph, edited by F. E. M. Hercules, was the journal of the Society of Peoples of African Origin. West African businessman John Eldred Taylor financed the newspaper. During the First World War the paper supported the war effort in the hope that service for the empire would strengthen black calls for increased representation in colonial government.

${ }^{46}$. Evening News, 24 Jan. 1919, 5.

47. Evening News, 29 Jan. 1919, 3.

${ }^{48}$. Evening Times, 29 Jan. 1919, 2.

49. Evening Citizen, 29 Jan., 1919, 3.

${ }^{50}$. Lunn, ed., Race and Labour, 17.

${ }^{51}$. Evening Citizen, 29 Jan. 1919, 3.

52. Workers' Dreadnought (London), 7 June 1919, 1354.

53. Workers' Dreadnought, 21 June 1919, 1368.

${ }^{54}$. Socialist (Glasgow), 10 July 1919, 264.

${ }^{55}$. Socialist, 10 July 1919, 264.

${ }^{56}$. M. Davis, Sylvia Pankhurst: a life in radical politics, (London, 1999), 58.

57 . This was part of a three-year crusade by Morel, made infamous by his widely circulated pamphlet 'Horror on the Rhine' against the use of black colonial troops against white Europeans, including allegations of the rape of German women by French North African troops.

${ }^{58}$. Evening News, 24 Jan. 1919, 5.

59. Evening News, 24 Jan. 1919, 5.

${ }^{60}$. There was a series of violent attacks against Germans in Britain between August 1914 and July 1918; which resulted in 866 arrests and over 250 injuries. The anti-German riots became broadly anti-alien in nature as the homes and businesses of Scandinavians, Italians, Russians, and particularly, Chinese, were also damaged. Russian Jews were subjected to riotous attacks in 1917 in Leeds and the east end of London due to the accusation that men from this group avoided military service. See P. Panayi, 'Anti-German riots in Britain during the First World War', in Panayi ed., Racial Violence in Britain, 65-91.

${ }^{61}$. Holmes, John Bull's Island, 95-114 and A Tolerant Country? (London, 1991), 23-8 and T. Kushner and K. Lunn, eds., The Politics of Marginality: race, the radical right and minorities in twentieth century Britain (London, 1990); and Kushner and T. Ceserani, eds., The Internment of Aliens in Britain (London, 1993).

62. J.A. Garrard, The English and Immigration, 1880-1910 (Oxford, 1971).

63 . The employment of any aliens (or those assumed to be aliens) at a time when demobilised British exservice personnel were looking for work provoked wide concern. For example, see HOC debates vol. 114, 1 Apr. 1919, col. 1062. 
${ }^{64}$. Daily Record, 25 Jan. 1919, 5.

65. C. Fyfe, A History of Sierra Leone (Oxford, 1962), 26.

${ }^{66}$. The Bulletin, 25 Jan. 1919, 10.

67. Evening Times, 29 Jan. 1919, 2.

${ }^{68}$. Evening Citizen, 29 Jan. 1919, 3.

${ }^{69}$. Cook’s first entry in the Glasgow Post Office Directory dates from 1897, the last 1934.

${ }^{70}$. Evening Times, 29 Jan. 1919, 2.

${ }^{71}$. Evening Times, 29 Jan. 1919, 2.

${ }^{72}$. Glasgow City Archives, Mitchell Library, Glasgow, Magistrates’ Committee Minutes, Glasgow

Corporation, 18 Feb. 1919.

${ }^{73}$. Evening News, 24 Jan. 1919, 5.

${ }^{74}$. Evening News, 18 June 1919, 2.

${ }^{75}$. Evening News, 24 Jan. 1919, 5.

${ }^{76}$. Glasgow Health Board Archive, Mitchell Library, Western Infirmary (Glasgow) admission book, 23 Jan. 1919, HH66/36/22 and also HH66 34/11, Case book, ward 34, 17-19.

${ }^{77}$. Bulletin, 24 Jan. 1919, 2.

${ }^{78}$. Evening News, 14 Feb. 1919, 3.

79. Jenkinson, in Panayi ed., Racial Violence in Britain, 98-102.

${ }^{80}$. Daily Post and Mercury (Liverpool), 11 June 1919, 3.

${ }^{81}$. Workers' Dreadnought, 7 June 1919, 1354.

82. Jenkinson, in Panayi, Racial Violence in Britain, 103-108.

${ }^{83}$. Bulletin, 14 June 1919, 14.

${ }^{84}$. TNA, Colonial Office [CO] 323/814, Note from Graeme Thomson, Ministry of Shipping to Gilbert Grindle, assistant under secretary, Colonial Office, 20 June 1919.

${ }^{85}$. Bulletin, 23 June 1919, 12.

${ }^{86}$. Evening Times, 18 June 1919, 2.

87. Cinema screenings of a version of 'Uncle Tom's Cabin' took place in Glasgow in the week of the harbour riot. A press account referred to the film as 'this pathetic and quaint story', Evening News, 23 Jan. 1919, 5.

${ }^{88}$. D. Lorimer, Colour, Class and the Victorians: English attitudes to the Negro in the mid-nineteenth century (Leicester, 1978), 89-90.

${ }^{89}$. Evening News, 18 June 1919, 2.

${ }^{90}$. The port riot in Newport, south Wales in June 1919 broke out within hours' of the local evening newspaper, the Monmouthshire Evening Post heavily featuring the outbreak of the rioting at Liverpool. However, there is no direct evidence of the Liverpool riots or the reporting of them having 'triggered' the Newport riot.

${ }^{91}$. Evening Times, 18 June 1919, 2. 
92. Evening Times, 21 June 1919, 2.

93. Evening Times, 1 July 1919, 2.

94 . Evening Times, 19 June 1919, 1.

${ }^{95}$. This club was set up by sometime sailor and ex-soldier, West Indian Cornelius Johnstone at the end of the war. The club was licensed as a private 'coloured men's' club, but was later illegally used as a public dance hall for which admission was charged. A police raid found the club 'packed full' with black and white men and white 'girls'. Johnstone and two white men were convicted of running an illegal dance hall. Johnstone was fined £10; his accomplices were fined $£ 5$ and £1. Glasgow Herald, 3 Nov. 1919, 9.

${ }^{96}$. Daily Record, 25 June 1919, 8.

${ }^{97}$. Letter from 'colonial jock', in fact Cornelius Johnstone, owner of the black social club discussed earlier, Daily Record, 20 June 1919, 8.

${ }^{98}$. Daniels's letter informed Moton that he had been elected honorary president of ARAG. Despite the flattery, Moton declined to financially support the association. He replied: 'I would urge you to draw just as largely as you can upon our own people there in Glasgow for the support of your movement. From what I saw of them, they are far from being poverty stricken...' R.R. Moton to Leo W. Daniels, 29 Dec. 1922, Tuskegee Institute Archives, R.R. Moton Papers, Box 9c-80, File 597.

99. I. Geiss, The Pan-African Movement, (London, 1974) 299.

${ }^{100}$. The ARAG committee list was cited in Daniels’ letter to Moton, 22 Dec. 1922, Moton Papers, Box 9c80, File 597.

101. B. Willan, Sol Plaatje: South Africa Nationalist, 1876-1932 (London, 1984), 186.

${ }^{102}$. Forward (Glasgow), 22 Oct. 1919, 2.

${ }^{103}$. The muckraking, ultra-patriotic journal John Bull was edited by some time MP and financial swindler, Horatio Bottomley.

${ }^{104}$. TNA, CO 323/812, Letter from sailors in Glasgow to the offices of John Bull, forwarded to the CO, 4 Mar. 1919.

105. John Bull, 29 March 1919, 7.

${ }^{106}$. African Telegraph, vol. 1, Apr. 1919, 184.

${ }^{107}$. TNA, MT 4/761, Marine Department, Board of Trade letter to all Mercantile Marine Offices, 17 Feb. 1919.

${ }^{108}$. By the end of July 1919 the Home Office confirmed 600 repatriations. TNA CO 323/815 604-606, 30 July 1919. In mid August, 45 ‘Arab’ Britons left for Aden; in early September, 225 West Indians left Cardiff for Barbados; another 45 West Indians were repatriated to Barbados, where they arrived in late December 1919. TNA CO 323/815 668, Ministry of Shipping to CO, 13 Aug. 1919; Western Mail (Cardiff), 11 Sept. 1919, 6; TNA CO 318/349, Governor of Barbados to CO, 24 Dec. 1919. Together these sailings make up a figure of 915 black and ‘Arab’ people repatriated between June and December 1919. Repatriation with financial inducements ended in November 1919, but limited government sponsored repatriation of smaller groups continued until 1921. State repatriation was augmented by repatriations by 
shipping companies. Elder Dempster repatriated 100 sailors from Liverpool to West Africa in June 1919. TNA HO 45/11017/377969, HO internal memorandum, 16 June 1919. The company repatriated a further 627 of its 'own' West African sailors from Liverpool in the eighteen months down to August 1921. West Africa, vol. 5, No. 237 (13 Aug. 1921), 845.

109. TNA, CO 323/818, CO internal memorandum, 2 May 1919.

${ }^{110}$. TNA, CO 323/818, Draft CO reply to ‘delegates of coloured seamen in Glasgow', 2 May 1919.

111. TNA, CO 323/813, Letter from ‘delegates of coloured seamen in Glasgow’ to CO, 7 May 1919.

112. Glasgow Herald, 26 Feb. 1920, 10.

${ }^{113}$. TNA, CO 323/843, Colonial Office memorandum on destitute seamen in Glasgow, 14 Feb. 1920.

114. Glasgow Herald, 5 Mar. 1920, 6. 